\title{
ANALISIS PENGARUH PELAKSANAAN SISTEM PENAGIHAN AKTIF TERHADAP TINGKAT PENCAIRAN TUNGGAKAN WAJIB PAJAK ORANG PRIBADI PADA KANTOR PELAYANAN PAJAK PRATAMA MANADO
}

\author{
Sumaryani Ode Alumu ${ }^{1}$, Stanly W. Alexander ${ }^{2}$, Sonny Pangerapan ${ }^{3}$ \\ ${ }^{1,2,3}$ Jurusan Akuntansi, Fakultas Ekonomi dan Bisnis, Universitas Sam Ratulangi, Jl. Kampus Unsrat, Manado, \\ 95115, Indonesia \\ E-mail : sumaryaniyani56@gmail.com
}

\begin{abstract}
Tax is a very potential alternative in order to raise the fund. Based on that, then increased public awareness in this regard should be supported with an increase in the taxation of an active role in gonverment to improve people's welfare and encoraging people to take responsiblity and play o role in the development of economic development. The purpose of this research is to know whether exist or not the influence of activated the billing system on taxpayer's. The research methode used simple linear regression analysis and for data was processed using SPSS V.17, The results showed that the relationship between the active billing with the level of tax arrears of individual taxpayer's in the Tax Office Primary Manado no significant effect and classified as ineffective with the value of correlation Pearson of letter warning of -.299 and a letter of force of -370, while the contributions given billing active of delinquent disbursement personal taxpayer's is 18,3\%, the rest of it is $81,7 \%$, disbursement of tax is affected by other which are not examined in this research.
\end{abstract}

Keywords : Active Billing Implementation, Disbursement of Tax Arrears

\section{PENDAHULUAN}

Negara Republik Indonesia adalah negara hukum berdasarkan Pancasila dan Undangundang Dasar 1945. Di dalam negara hukum, setiap aspek tindakan pemerintah baik dalam lapangan pengaturan maupun dalam lapangan pelayanan harus didasarkan pada peraturan perundang-undangan serta dijiwai dengan pembangunan hukum nasional. Pembangunan hukum nasional merupakan bagian dari pembangunan nasional yang perlu dilaksanakan secara berkesinambungan serta merata di seluruh tanah air yang bertujuan untuk meningkatkan kehidupan bangsa dan negara secara adil, makmur dan merata di seluruh lapisan rakyat Indonesia. Kendala dana yang tidak sedikit merupakan salah satu hambatan yang mengganggu tercapainya tujuan pembangunan nasional. Pajak merupakan alternatif yang sangat potensial dalam rangka peningkatan dana. Berdasarkan hal itu maka peningkatan kesadaran masyarakat dalam hal ini perpajakan harus didukung dengan peningkatan peran aktif dalam melaksanakan peraturan perundang-undangan perpajakan.

Indonesia menganut Sistem self-assessment berdasarkan Undang-Undang No. 28 Tahun 2007 tentang Ketentuan Umum dan Tata Cara Perpajakan khususnya ayat 1 dan 2. Berdasarkan ketentuan tersebut, maka wajib pajak wajib untuk melakukan kegiatan menghitung, membayar, dan melaporkan melalui surat pemberitahuan. Kepercayaan yang telah diberikan oleh pemerintah terhadap wajib pajak dalam sistem self-assessment ini seharusnya dapat berjalan sesuai rencana. Wajib pajak mampu melaksanakan kewajiban perpajakannya secara baik tanpa adanya kelalaian, kesengajaan, maupun ketidaktahuan atas kewajibannya tersebut. Upaya untuk meminimalisasi adanya tindakan tersebut maka perlu adanya penegakan hukum (law enforcement) atas kepatuhan wajib pajak. Kepatuhan dalam hal ini contohnya adalah kewajibannya dalam membayar pajak yang terutang tetapi dibayar terlambat ataupun belum dibayar. 
Negara Indonesia memberikan tanggung jawab kepada Direktorat Jenderal Pajak (DJP) untuk bertindak sebagai law enforcement agent. Hal tersebut dilakukan Direktorat Jenderal Pajak untuk mengoptimalisasi penerimaan pajak yang masih terhalangi oleh beberapa kendala. Produk hukum berupa peraturan perpajakan yang lebih baik diharapkan dapat memberikan penekanan yang lebih pada keseimbangan antara kepentingan masyarakat, wajib pajak dan kepentingan negara.

Perkembangan keadaan yang terjadi di masyarakat dan didukung adanya reformasi, Undang-Undang No. 19 Tahun 1997 diubah menjadi Undang-Undang No. 19 Tahun 2000, tetapi kenyataannya hutang pajak yang belum dilunasi oleh wajib pajak masih menjadi hambatan yang besar. Hutang pajak yang belum dilunasi sering dihadapi karena peningkatan jumlah tunggakan pajak masih belum bisa diimbangi oleh kegiatan pencairan. Telah dilakukan berbagai tindakan penagihan pajak oleh fiskus terhadap wajib pajak dan/atau penanggung pajak dengan penagihan pasif maupun aktif.

\section{Tujuan Penelitian}

1. Untuk mengetahui tingkat pengaruh penagihan pajak dengan sistem penagihan aktif terhadap pencairan tunggakan pajak.

2. Untuk mengetahui pelaksanaan sistem penagihan aktif terhadap pencairan tunggakan pajak sudah efektif.

3. Untuk mengetahui apakah ada peningkatan penerimaan dengan menggunakan sistem penagihan aktif terhadap pencairan tunggakan.

\section{TINJAUAN PUSTAKA}

\section{Akuntansi Pajak}

Agoes dan Estralita ( 2013: 10) akuntansi pajak adalah menetapkan besarnya pajak terutang berdasarkan laporan keuangan yang disusun oleh perusahaan.

\section{Pajak}

Definisi pajak menurut Undang-Undang No. 16 Tahun 2009 tentang perubahan keempat atas Undang-Undang No. 6 Tahun 1983 tentang Ketentuan Umum dan Tata Cara Perpajakan pada Pasal 1 ayat (1) berbunyi pajak adalah kontribusi wajib pajak kepada negara yang terutang oleh orang pribadi atau badan yang bersifat memaksa berdasarkan undangundang, dengan tidak mendapatkan imbalan secara langsung dan digunakan untuk keperluan negara bagi sebesar-besarnya kemakmuran rakyat.

\section{Fungsi Pajak}

Menurut Thomas Sumarsan (2013: 5) pajak mempunyai beberapa fungsi yaitu :

1. Fungsi Penerimaan (Budgetair)

2. Fungsi Mengatur (regulerend)

\section{Asas Pemungutan Pajak}

Menurut Waluyo (2013: 16), asas-asas pemungutan pajak dapat dikelompokkan dalam 3 jenis, yaitu :

1. Asas Tempat Tinggal

2. Asas Kebangsaan

3. Asas Sumber

\section{Sistem Pemungutan Pajak}

Menurut Waluyo (2013: 17), sistem pemungutang pajak dapat dibagi menjadi 3 yaitu :

1. Official Assessment System

2. Self Assessment System

3. Withholding System 


\section{Pengertian Penagihan Pajak}

Penagihan pajak menurut Pasal 1 angka (9) Undang-Undang No. 19 Tahun 1997 tentang Penagihan Pajak dengan Surat Paksa sebagaimana telah diubah terakhir dengan Undang-Undang No. 19 Tahun 2000 sebagai berikut : "Penagihan pajak adalah serangkaian tindakan agar penanggung pajak melunasi utang pajak dan biaya penagihan pajak dengan menegur atau memperingatkan, melaksanakan penagihan seketika dan sekaligus, memberitahukan surat paksa, mengusulkan pencegahan, melakukan penyitaan, melaksanakan penyaderaan, menjual barang yang telah disita,"

\section{Dasar Hukum Penagihan Pajak}

Dasar hukum penagihan pajak adalah Undang-Undang No. 19 Tahun 1997 tentang Penagihan Pajak dengan Surat Paksa sebagaimana telah diubah dengan Undang-Undang No. 19 Tahun 2000.

\section{Jadwal Pelaksanaan Penagihan Pajak}

Surat yang diterbitkan pejabat sebagai penagihan pajak tersebut pelaksanaannya terjadwal, yaitu sebagai berikut :

1. Tindakan pelaksanaan penagihan pajak dengan surat teguran oleh pejabat dilakukan setelah 7 (tujuh) hari sejak saat jatuh tempo pembayaran. Surat teguran itu tidak diterbitkan jika penanggung pajak mendapat persetujuan untuk mengangsur atau menunda pembayaran pajak.

2. Menerbitkan surat paksa, apabila jumlah utang pajak yang masuk harus dibayar tetap tidak dilunasi oleh penanggung pajak setelah lewat 21 (dua puluh satu) hari sejak diterbitkannya surat teguran maka pejabat segera menerbitkan surat paksa.

3. Menerbitka Surat Perintah Melaksanakan Penyitaan (SPMP) bila jumlah utang pajak yang masih harus dibayar tidak dilunasi oleh penanggung pajak setelah lewat $2 \times 24$ jam sejak surat paksa diterbitkan.

\section{Tindakan Penagihan}

Menurut Suandy (2014: 173) dalam Marduati (2013) penagihan pajak dapat dikelompokkan menjadi 2 yaitu sebagai berikut :

1. Penagihan pajak pasif

2. Penagihan pajak aktif

\section{Prosedur Penagihan Aktif}

Dalam pelaksanaan penagihan aktif tersebut dapat dilakukan dengan 4 tahap, yaitu :

1. Penagihan Dengan Surat Teguran

2. Penagihan Dengan Surat Paksa

3. Surat Perintah Melaksanakan Penyitaan (SPMP)

4. Pengumuman Lelang

5. Pelaksanaan Lelang

\section{Penelitian Terdahulu}

Ratih Diah Ratna Paramitha (2013) dengan judul analisis pengaruh pelaksanaan sistem penagihan aktif terhadap tingkat pencairan tunggakan wajib pajak. Tujuan penelitian ini untuk mengetahui pengarug sistem penagihan aktif terhadap tingkat pencairan tunggakan pajak. Metode yang digunakan adalah regresi linier sederhana. Hasil penelitian yang diperoleh adalah berpengaruh signifikan terhadap tingkat pencairan tunggakan wajib pajak.

\section{METODE PENELITIAN}

\subsection{Jenis Penelitian}

\section{Jenis Penelitian}

Jenis penelitian yang digunakan dalam penulisan skripsi ini adalah penelitian kuantitatif yaitu data yang dapat diinput ke dalam skala pengukuran statistik yang lebih menekankan pada aspek pengukuran secara obyektif terhadap fenomena sosial. 


\section{Tempat dan Waktu Penelitian}

Adapun tempat penelitian ini dilakukan di Kantor Pelayanan Pajak Pratama Manado. Proses pengumpulan dan pengolahan data untuk penelitian ini dilakukan mulai bulan April s/d Juni 2017.

\section{Variabel Penelitian dan Definisi Operasional}

Variabel operasional yang digunakan dalam penelitian ini melibatkan tiga variabel yang terdiri atas dua variabel independen (bebas) dan satu variabel dependen (terikat) yaitu :

a. Surat Teguran (X1)

Surat teguran adalah surat yang diterbitkan oleh KPP untuk menegur atau memperingatkan kepada Wajib Pajak untuk melunasi utang pajaknya. Variabel surat teguran yang diterbitkan dilihat dari banyaknya jumlah surat teguran yang diterbitkan.

b. Surat Paksa (X2)

Surat Paksa adalah surat perintah yang dikeluarkan oleh KPP dan dilakukan oleh juru sita untuk memaksa Wajib Pajak melunasi utang pajak dalam jangka waktu tertentu. Penagihan pajak dengan surat paksa, dalam hal ini dilihat dari jumlah surat paksa yang diterbitkan.

c. Pencairan Tunggakan Pajak (Y)

Pencairan tunggakan pajak adalah segala bentuk pencairan yang berkaitan dengan tunggakan pajak yang disetorkan ke kas negara yang dapat berupa pembayaran, penghapusan, pemindahbukuan, maupun keberatan. Variabel pencairan tunggakan pajak dilihat dari jumlah pembayaran atas pajak yang terutang yang didasarkan pada STP, SKP, SKPKB, SKPKBT.

\section{Uji Linieritas}

Linieritas adalah keadaan dimana hubungan antara variabel terikat dengan variabel bebas bersifat linier (garis lurus) dalam range variabel bebas tertentu. Uji linieritas bertujuan untuk mengetahui apakah 2 variabel mempunyai hubungan yang linier atau tidak secara signifikan. Uji ini biasanya digunakan sebagai prasyarat dalam analisis korelasi atau regresi linier.

\section{Uji Asumsi Klasik}

Dalam penggunaan regresi, terdapat beberapa asumsi dasar yang menghasilkan estimator linear tidak biasa yang terbaik dari model regresi yang diperoleh dari metode kuadrat terkecil biasa. Dengan terpenuhinya asumsi-asumsi tersebut maka hasil yang diperoleh dapat lebih akurat dan mendekati atau sama dengan kenyataannya. Klasik asumsi-asumsi dasar itu dikenal sebagai asumsi klasik yaitu sebagai berikut :

1. Uji Normalitas

2. Uji Multikolinieritas

\section{Analisis Regresi Linier Berganda}

Menurut (Sugiyono 2013:277) bahwa "analisis regresi berganda digunakan untuk meramalkan bagaimana keadaan (naik turunnya) variabel dependen, bila dua atau lebih variabel independen sebagai faktor prediktor dimanipulasi (dinaik turunkan nilainya)". Jadi analisis regresi berganda akan dilakukan bila jumlah variabel independennya minimal dua.

Rumus linier berganda ditunjukkan oleh persamaan :

$$
\mathrm{Y}=\mathrm{a}+\mathrm{b} 1 \mathrm{X} 1+\mathrm{b} 2 \mathrm{X} 2+\mathrm{e}
$$

Dimana :

$\mathrm{Y}=$ Jumlah pencairan tunggakan pajak

$\mathrm{a} \quad=$ Kostanta

$\mathrm{b} 1=$ Koefisien surat teguran

b2 = Koefiisen surat paksa

$\mathrm{X} 1=$ Surat teguran 


\section{Uji Hipotesis}

$$
\begin{array}{ll}
\mathrm{X} 2 & =\text { Surat paksa } \\
\mathrm{e} & =\text { Faktor Pengganggu }
\end{array}
$$

1. Uji Parsial ( $\mathrm{t}$-test)

Uji signifikansi secara parsial atau sering kali disebut uji t bertujuan untuk melihat pengaruh variabel-variabel independen secara individual terhadap variabel dependen.

2. Uji Simultan (F-test)

Uji signifikansi simultan atau sering kali disebut uji $\mathrm{F}$ bertujuan untuk melihat pengaruh variabel-variabel bebas secara bersama-sama terhadap variabel terikat.

3. Koefisien Determinasi (R)

Koefisien determinasi digunakan untuk mengukur seberapa besar peranan variabel bebas (independen) menjelaskan perubahan yang terjadi pada variabel terikat (dependen). Nilai koefisien determinasi adalah antara 0 sampai 1.

\section{HASIL ANALISIS DAN PEMBAHASAN}

\subsection{Hasil Penelitian}

\section{Rencana dan Realisasi Penerimaan Pajak Di KPP Pratama Manado}

Berikut ini adalah tabel target dan realisasi penerimaan pajak di KPP Pratama Manado untuk tahun 2014-2016 adalah sebagai berikut :

\section{Rencana dan Realisasi Penerimaan Pajak \\ Tahun 2014-2016}

\begin{tabular}{|c|c|c|c|}
\hline Tahun & $\begin{array}{c}\text { Target } \\
\text { Penerimaan }\end{array}$ & $\begin{array}{c}\text { Realisasi } \\
\text { Penerimaan }\end{array}$ & Kontribusi \\
\hline 2014 & $1,569,331,355,000$ & $1,337,248,703,454$ & $85,22 \%$ \\
\hline 2015 & $2,319,995,459,538$ & $1,390,399,205,297$ & $59,93 \%$ \\
\hline 2016 & $2,564,419,439,000$ & $1,786,629,727,427$ & $69,66 \%$ \\
\hline \multicolumn{4}{|c|}{ Sumber : Seksi Pengolahan Data dan Informasi KPP Pratama Manado } \\
\hline
\end{tabular}

Kondisi Tunggakan Wajib Pajak Orang Pribadi Di KPP Pratama Manado

Berikut adalah data mengenai kondisi tunggakan wajib pajak orang pribadi di KPP Pratama Manado yang disajikan dalam tahun 2014-2016 :

\section{Laporan Tunggakan Pajak \\ Tahun 2014-2016}

\begin{tabular}{|c|c|}
\hline \multicolumn{1}{c|}{ (dalam rupiah) } \\
\hline Tahun & Jumlah Tunggakan Pajak \\
\hline 2014 & $47,332,791,800$ \\
\hline 2015 & $66,622,920,967$ \\
\hline 2016 & $73,938,414,959$ \\
\hline \multicolumn{2}{|c|}{ Sumber :Seksi Penagihan KPP Pratama Manado } \\
\hline
\end{tabular}

Tunggakan pajak yang ada di KPP Pratama Manado berasal dari STP/SKPKB/SKPBT yang belum lunas dan telah lewat tanggal jatuh tempo pembayaran, surat keputusan pembetulan, surat keputusan keberatan, putusan banding, putusan peninjauan kembali yang menyebabkan jumlah pajak yang masih harus dibayar bertambah. Penambahan jumlah tunggakan berasal dari kenaikan tunggakan pada triwulan berjalan. 


\section{Jumlah Surat Teguran dan Surat Paksa yang Diterbitkan Serta Pencairan Tunggakan Pajak (Tahun 2014-2016)}

\begin{tabular}{|c|c|c|c|}
\hline Bulan & $\begin{array}{c}\text { Surat Teguran yang } \\
\text { Diterbitkan (X1) }\end{array}$ & $\begin{array}{c}\text { Surat Paksa yang } \\
\text { Diterbitkan } \\
(\mathbf{X 2 )}\end{array}$ & $\begin{array}{c}\text { Pencairan Tungggakan } \\
\text { Pajak } \\
\text { (Y) }\end{array}$ \\
\hline Januari (2014) & 40 & 38 & 917,889 \\
\hline Februari & 38 & 31 & 856,567 \\
\hline Maret & 42 & 40 & 489,258 \\
\hline April & 40 & 37 & 665,340 \\
\hline Mei & 38 & 38 & 313,061 \\
\hline Juni & 34 & 27 & 598,241 \\
\hline Juli & 44 & 40 & 332,527 \\
\hline Agustus & 31 & 30 & 765,810 \\
\hline September & 39 & 35 & 543,672 \\
\hline Oktober & 44 & 42 & 462,838 \\
\hline November & 39 & 50 & 666,328 \\
\hline Desember & 30 & 25 & 567,432 \\
\hline Total & $\mathbf{4 5 9}$ & $\mathbf{4 3 3}$ & $\mathbf{7 , 1 7 8 , 9 6 3}$ \\
\hline
\end{tabular}

\begin{tabular}{|c|c|c|c|}
\hline Bulan & $\begin{array}{c}\text { Surat Teguran yang } \\
\text { Diterbitkan (X1) }\end{array}$ & $\begin{array}{c}\text { Surat Paksa yang } \\
\text { Diterbitkan } \\
\text { (X2) }\end{array}$ & $\begin{array}{c}\text { Pencairan Tungggakan } \\
\text { Pajak } \\
\text { (Y) }\end{array}$ \\
\hline Januari (2015) & 100 & 100 & $3,574,908$ \\
\hline Februari & 95 & 100 & $3,569,248$ \\
\hline Maret & 86 & 85 & $2,625,243$ \\
\hline April & 79 & 72 & $3,569,528$ \\
\hline Mei & 55 & 75 & $2,175,462$ \\
\hline Juni & 68 & 67 & $1,413,456$ \\
\hline Juli & 77 & 80 & $2,218,286$ \\
\hline Agustus & 90 & 87 & $2,873,564$ \\
\hline September & 80 & 80 & $2,584,651$ \\
\hline Oktober & 77 & 75 & $1,197,579$ \\
\hline November & 67 & 62 & 712,341 \\
\hline Desember & 80 & 78 & 945,164 \\
\hline Total & $\mathbf{9 5 4}$ & $\mathbf{9 6 1}$ & $\mathbf{2 7 , 4 5 8 , 4 3 0}$ \\
\hline
\end{tabular}

\begin{tabular}{|c|c|c|c|}
\hline Bulan & $\begin{array}{c}\text { Surat Teguran yang } \\
\text { Diterbitkan (X1) }\end{array}$ & $\begin{array}{c}\text { Surat Paksa yang } \\
\text { Diterbitkan } \\
(\mathbf{X})\end{array}$ & $\begin{array}{c}\text { Pencairan Tungggakan } \\
\text { Pajak } \\
\text { (Y) }\end{array}$ \\
\hline Januari (2016) & 140 & 135 & $5,756,820$ \\
\hline Februari & 118 & 110 & $4,242,511$ \\
\hline Maret & 102 & 90 & $3,061,425$ \\
\hline April & 120 & 114 & $3,896,488$ \\
\hline Mei & 92 & 90 & $2,954,771$ \\
\hline Juni & 100 & 95 & $3,133,359$ \\
\hline Juli & 95 & 93 & $2,965,210$ \\
\hline Agustus & 70 & 70 & $1,728,165$ \\
\hline September & 80 & 61 & $2,871,255$ \\
\hline Oktober & 77 & 80 & $3,658,748$ \\
\hline November & 58 & 83 & $1,810,733$ \\
\hline Desember & 30 & 36 & $1,520,820$ \\
\hline Total & $\mathbf{1 . 0 8 2}$ & $\mathbf{1 . 0 5 7}$ & $\mathbf{3 7 , 6 0 0 , 3 0 5}$ \\
\hline
\end{tabular}




\section{Pembahasan}

\section{Statistik Deskriptif}

Hasil statistik deskriptif dari masing-masing variabel disajikan dalam tabel sebagai berikut :

\section{Statistik Deskriptif}

Descriptive Statistics

\begin{tabular}{|c|r|r|r|}
\hline & \multicolumn{1}{|c|}{ Mean } & Std. Deviation & $\mathrm{N}$ \\
\hline $\begin{array}{c}\text { jumlah pencairan } \\
\text { tunggakan pajak }\end{array}$ & 2006630.50 & 1389267.234 & 36 \\
$\begin{array}{c}\text { Jumlah surat teguran yang } \\
\text { diterbtkan }\end{array}$ & 69.31 & 29.147 & 36 \\
$\begin{array}{c}\text { Jumlah surat paksa yang } \\
\text { diterbitkan }\end{array}$ & 68.08 & 28.352 & 36 \\
\hline
\end{tabular}

Dari tabel di atas menunjukkan bahwa jumlah sampel yang digunakan adalah sebanyak 36 sampel. Selain itu, dalam tabel di atas menunjukkan :

Rata-rata jumlah pencairan tunggakan pajak adalah 2006630.50 dengan standar deviasi 1389267.234 .

Rata-rata jumlah surat teguran yang diterbitkan adalah 69.31 dengan standar deviasi 29.147. Rata-rata jumlah surat paksa yang diterbitkan adalah 68.08 dengan standar deviasi 28.352.

\section{Pengujian Asumsi Klasik}

\section{Output Pengujian Normalitas}

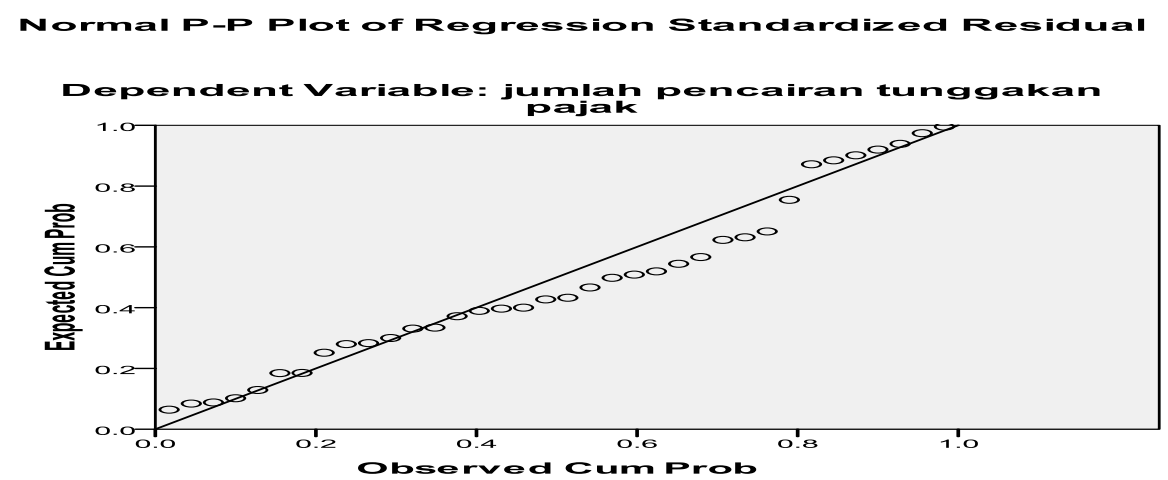

Dari gambar di atas terlihat bahwa data (titik) menyebar di sekitar garis diagonal dan penyebarannya mengikuti arah garis diagonal sehingga dapat disimpulkan bahwa data yang diolah adalah data yang berdistribusi normal yang artinya uji normalitas terpenuhi.

\section{Analisis Korelasi Pearson}

Uji korelasi bertujuan untuk mengetahui tingkat keeratan hubungan antara variabel yang dinyatakan dengan koefisien korelasi (r). Dengan jenis hubungan antar variabel X dan Y dapat bersifat positif atau negatif. 


\section{Output Korelasi Pearson Correlations}

\begin{tabular}{|c|c|c|c|c|}
\hline & & $\begin{array}{l}\text { jumlah } \\
\text { pencairan } \\
\text { tunggakan } \\
\text { pajak }\end{array}$ & $\begin{array}{c}\text { Jumlah surat } \\
\text { teguran yang } \\
\text { diterbitkan }\end{array}$ & $\begin{array}{c}\text { Jumlah surat } \\
\text { paksa yang } \\
\text { diterbitkan }\end{array}$ \\
\hline \multirow[t]{3}{*}{ Pearson Correlation } & $\begin{array}{c}\text { jumlah pencairan } \\
\text { tunggakan pajak }\end{array}$ & 1.000 & -.299 & -.370 \\
\hline & $\begin{array}{l}\text { Jumlah surat teguran yang } \\
\text { diterbtkan }\end{array}$ & -.299 & 1.000 & .964 \\
\hline & $\begin{array}{c}\text { Jumlah surat paksa yang } \\
\text { diterbitkan }\end{array}$ & -.370 & .964 & 1.000 \\
\hline \multirow[t]{3}{*}{ Sig. (1-tailed) } & $\begin{array}{l}\text { jumlah pencairan } \\
\text { tunggakan pajak }\end{array}$ & & .038 & .013 \\
\hline & $\begin{array}{l}\text { Jumlah surat teguran yang } \\
\text { diterbtkan }\end{array}$ & .038 & & .000 \\
\hline & $\begin{array}{c}\text { Jumlah surat paksa yang } \\
\text { diterbitkan }\end{array}$ & .013 & .000 & \\
\hline \multirow[t]{3}{*}{$\mathrm{N}$} & $\begin{array}{c}\text { jumlah pencairan } \\
\text { tunggakan pajak }\end{array}$ & 36 & 36 & 36 \\
\hline & $\begin{array}{l}\text { Jumlah surat teguran yang } \\
\text { diterbtkan }\end{array}$ & 36 & 36 & 36 \\
\hline & $\begin{array}{c}\text { Jumlah surat paksa yang } \\
\text { diterbitkan }\end{array}$ & 36 & 36 & 36 \\
\hline
\end{tabular}

\section{Dasar Pengambilan Keputusan :}

1. Jika nilai sig $<0.05$ maka berkorelasi

2. Jika nilai sig $>0.05$ maka tidak berkorelasi

Dari tabel di atas dapat diketahui nilai signifikansinya $0.013>0.05$ bersifat positif dan tidak berkorelasi. Maka dapat dikatakan tidak terdapat hubungan antara surat teguran dan surat paksa yang diterbitkan dengan jumlah pencairan tunggakan pajak.

\section{Pedoman Derajat Hubungan :}

1. Nilai Pearson Correlation $0.00 \mathrm{~s} / \mathrm{d} 0.20=$ tidak ada korelasi

2. Nilai Pearson Correlation $0.21 \mathrm{~s} / \mathrm{d} 0.40=$ korelasi lemah

3. Nilai Pearson Correlation $0.41 \mathrm{~s} / \mathrm{d} 0.60=$ korelasi sedang

4. Nilai Pearson Correlation $0.61 \mathrm{~s} / \mathrm{d} 0.80=$ korelasi kuat

5. Nilai Pearson Correlation $0.81 \mathrm{~s} / \mathrm{d} 1.00=$ korelasi sempurna

Nilai pearson correlation untuk surat teguran adalah sebesar -.299 dan untuk surat paksa adalah sebesar - .370 bersifat negatif dan tidak berkorelasi Maka dapat dikatakan tidak memiliki pedoman hubungan antara jumlah surat-surat yang diterbitkan dengan jumlah pencairan tunggakan pajak.

\section{Analisis Regresi Berganda}

Berikut bentuk model regresi berganda bertujuan dari penelitian ini berdasarkan tabel coefficients adalah : 


\section{Output Regresi Linier Berganda \\ Coefficients $^{\mathrm{a}}$}

\begin{tabular}{|c|c|c|c|c|c|c|}
\hline \multirow{2}{*}{\multicolumn{2}{|c|}{ Model }} & \multicolumn{2}{|c|}{ Unstandardized Coefficients } & $\begin{array}{l}\text { Standardized } \\
\text { Coefficients }\end{array}$ & \multirow[b]{2}{*}{$\mathrm{t}$} & \multirow[b]{2}{*}{ Sig. } \\
\hline & & B & Std. Error & Beta & & \\
\hline \multirow[t]{3}{*}{1} & (Constant) & 6090097.118 & 918266.790 & & 6.632 & .000 \\
\hline & $\begin{array}{l}\text { Jumlah surat teguran } \\
\text { yang diterbtkan }\end{array}$ & 61937.804 & 45457.799 & .806 & 1.363 & .182 \\
\hline & $\begin{array}{c}\text { Jumlah surat paksa yang } \\
\text { diterbitkan }\end{array}$ & -90579.901 & 46731.627 & -1.147 & -1.938 & .061 \\
\hline
\end{tabular}

a. Dependent Variable: jumlah pencairan tunggakan pajak berikut :

Berdasarkan hasil perhitungan di atas diperoleh persamaan regresi berganda sebagai

$$
\mathrm{Y}=6090097.118+61937.804 \mathrm{X} 1+(-90579.901 X 2)+\mathrm{e}
$$

Hasil persamaan regresi ini secara keseluruhan menunjukkan hasil interpretasi sebagai berikut :

1. Konstanta $(\alpha)$ sebesar 609.097.118 menyatakan bahwa jika tidak terdapat penerbitan surat teguran $\left(\mathrm{X}_{1}\right)$ dan penerbitan surat paksa $\left(\mathrm{X}_{2}\right)$ atau sama dengan nol maka jumlah pencairan tunggakan pajak (Y) nilainya adalah 609.097.118.

2. Koefisien regresi untuk penerbitan surat teguran $\left(\beta_{1}\right)$ sebesar 61.937 .804 artinya jika variabel lainnya tetap dan surat teguran mengalami kenaikan $1 \%$ maka pencairan tunggakan pajak akan mengalami pertambahan sebesar 61.937.804 kali. Koefisien bernilai positif artinya terjadi hubungan satu arah antara surat teguran dan pencairan tunggakan pajak.

3. Koefisien regresi untuk penerbitan surat paksa $\left(\beta_{2}\right)$ sebesar -90.579 .901 artinya jika variabel lainnya tetap dan surat paksa mengalami kenaikan $1 \%$ maka pencairan tunggakan tunggakan pajak akan mengalami penurunan sebesar -90.579 .901 kali. Koefisien bernilai negatif artinya terjadi hubungan berlawanan arah antara surat paksa dan pencairan tunggakan pajak.

\section{Uji Parsial (t-test)}

\section{Pengujian Dengan Nilai $t$ :}

a. Jika $t_{\text {hitung }}>t_{\text {tabel }} \mathrm{H} 0$ ditolak dan $\mathrm{H} 1$ diterima

b. Jika $t_{\text {hitung }}<\mathrm{t}_{\text {tabel }} \mathrm{H} 0$ diterima dan $\mathrm{H} 1$ ditolak

Pengujian Dengan Nilai Signifikansi (sig) :

a. Sig > $0.05 \mathrm{H} 0$ diterima dan $\mathrm{H} 1$ ditolak

b. Sig < 0.05 H0 ditolak dan H1 diterima

\section{Pengambilan Keputusan :}

1. Variabel surat teguran $\left(\mathrm{X}_{1}\right)$

a. Membandingkan $t_{\text {hitung }}$ dengan $t_{\text {tabel }}$

Dari tabel 4.7 diperoleh nilai $\mathrm{t}_{\text {hitung }}$ sebesar $1.363<\mathrm{t}_{\text {tabel }} 2.028$ maka H0 diterima dan H1 ditolak.

b. Berdasarkan tingkat signifikan

Berdasarkan tabel 4.7 terlihat nilai signifikan surat teguran sebesar $0.182>0.05$ maka H0 diterima dan H1 ditolak. Artinya surat teguran yang diterbitkan oleh KPP Pratama Manado tidak berpengaruh terhadap jumlah pencairan tunggakan pajak akibat penagihan aktif. 
2. Variabel surat paksa $\left(\mathrm{X}_{2}\right)$

a. Membandingkan $t_{\text {hitung }}$ dengan $t_{\text {tabel }}$

Dari tabel 4.7 diperoleh nilai $\mathrm{t}_{\text {hitung }}$ sebesar $-1.938<\mathrm{t}_{\text {tabel }} 2.028$ maka $\mathrm{H} 0$ diterima dan H1 ditolak.

b. Berdasarkan tingkat signifikan

Berdasarkan tabel 4.7 terlihat nilai signifikan surat teguran sebesar $0.061>0.05$ maka H0 diterima dan H1 ditolak. Artinya surat paksa yang diterbitkan oleh KPP Pratama Manado tidak berpengaruh terhadap jumlah pencairan tunggakan pajak akibat penagihan aktif.

\section{Uji Simultan (F-test)}

Pengujian hipotesis secara bersama-sama dilakukan dengan menggunakan uji F. Uji $F$ dilakukan untuk menguji hubungan signifikansi antara variabel bebas dengan variabel terikat secara keseluruhan. Untuk mendapatkan hasil yang meyakinkan maka akan dilakukan pengujian $F_{\text {hitung }}$ dan $F_{\text {tabel }}$ dengan tingkat signifikansi 0.05 atau 5\%. Hasil pengujian yang diperoleh sebagai berikut :

\section{Output Uji F}

\begin{tabular}{|rc|r|r|r|c|c|}
\hline \multicolumn{1}{|c|}{ ANOVA $^{\mathbf{b}}$} \\
\hline \multicolumn{1}{|c|}{ Model } & Sum of Squares & \multicolumn{1}{c|}{ df } & Mean Square & F & \multicolumn{1}{c|}{ Sig. } \\
\hline & Regression & $3.205 \mathrm{E} 13$ & 2 & $1.602 \mathrm{E} 13$ & 3.689 & $.036^{\mathrm{a}}$ \\
& Residual & $1.433 \mathrm{E} 14$ & 33 & $4.344 \mathrm{E} 12$ & & \\
& Total & $1.754 \mathrm{E} 14$ & 35 & & & \\
\hline
\end{tabular}

a. Predictors: (Constant), Jumlah surat paksa yang diterbitkan, Jumlah surat teguran yang diterbtkan

b. Dependent Variable: jumlah pencairan tunggakan pajak

Berdasarkan tabel di atas dapat diketahui bahwa nilai $F_{\text {hitung }}>F_{\text {tabel }}(3.689>3.285)$ maka $\mathrm{H} 0$ ditolak dan $\mathrm{H} 1$ diterima dengan kata lain terdapat pengaruh antara surat teguran dan surat paksa terhadap pencairan tunggakan pajak. Selain itu dapat dilihat nilai signifikansi $=0.036>0.05$ maka $\mathrm{H} 0$ diterima dan $\mathrm{H} 1$ ditolak atau dapat dikatakan koefisisen regresi signifikan.

\section{Analisis Model Summry}

Koefisien determinasi $\left(\mathrm{R}^{2}\right)$ digunakan untuk mengukur seberapa besar peranan variabel bebas (independen) yaitu surat teguran dan surat paksa secara bersama-sama menjelaskan perubahan yang terjadi pada variabel terikat (dependen) yaitu pencairan tunggakan pajak. Hasil pengujian sebagai berikut :

\section{Output Model Summary}

\begin{tabular}{|c|r|r|r|c|}
\hline Model & \multicolumn{1}{|c|}{ R } & R Square & $\begin{array}{c}\text { Adjusted R } \\
\text { Square }\end{array}$ & $\begin{array}{c}\text { Std. Error of } \\
\text { the Estimate }\end{array}$ \\
\hline 1 & $.427^{\mathrm{a}}$ & .183 & .133 & 2084106.529 \\
\hline
\end{tabular}

a. Predictors: (Constant), Jumlah surat paksa yang diterbitkan, Jumlah surat teguran yang diterbtkan

Berdasarkan tabel di atas dapat diketahui bahwa nilai R Square sebesar 0.183 atau 18.3\%. Hal ini berarti bahwa $18.3 \%$ variasi penerimaan pencairan tunggakan pajak dapat dijelaskan oleh variabel independen surat teguran dan surat paksa. Sedangkan sisanya $81.7 \%$ $(100 \%-18.3 \%)$ dijelaskan atau dipengaruhi variabel lain yang tidak dimasukkan dalam model penelitian ini. 


\section{KESIMPULAN DAN SARAN}

\subsection{Kesimpulan}

Berdasarkan hasil analisis yang telah dilakukan maka dapat diambil kesimpulan sebagai berikut :

1. Berdasarkan hasil uji Korelasi Pearson dapat diketahui bahwa sistem penagihan aktif yang dilakukan oleh KPP Pratama Manado sudah tergolong tidak efektif dengan hasil yang diperoleh dari analisis korelasi pearson untuk surat teguran sebesar -.299 dan untuk surat paksa adalah sebesar -.370 bersifat negatif dan tidak berkorelasi Maka dapat dikatakan tidak memiliki pedoman hubungan antara jumlah surat teguran dan surat paksa yang diterbitkan dengan jumlah pencairan tunggakan pajak.

2. Berdasarkan uji regresi, dimana uji t dapat diketahui bahwa sistem penagihan aktif tidak berpengaruh terhadap pencairan tunggakan pajak dengan hasil yang diperoleh untuk surat teguran $\mathrm{t}_{\text {hitung }} 1.363<\mathrm{t}_{\text {tabel }} 2.028$ dan surat paksa $\mathrm{t}_{\text {hitung }}-1.938<\mathrm{t}_{\text {tabel }} 2.028$ yang menunjukkan dari masing-masing surat yang diterbitkan oleh KPP Pratama Manado tidak berpengaruh terhadap jumlah pencairan tunggakan pajak akibat penagihan aktif

3. Berdasarkan hasil uji model summary pada nilai R Square dapat diketahui kontribusi yang diberikan oleh sistem penagihan aktif terhadap tingkat pencairan tunggakan pajak adalah sebesar $18.3 \%$ yang menunjukkan pengaruh surat teguran dan surat paksa sangat rendah terhadap perkembangan jumlah pencairan tunggakan pajak..

\subsection{Saran} adalah :

Saran yang dapat disampaikan kepada KPP Pratama Manado dari penelitian ini

1. Diharapkan aparat pajak melakukan tindakan tegas terhadap Wajib Pajak yang tidak kooperatif sesuai dengan ketentuan perpajakan yang ada dan berlaku di Indonesia.

2. Meningkatkan kesadaran Wajib Pajak dalam menunaikan kewajibannya membayar pajak melalui kegiatan penyuluhan-penyuluhan pajak secara intensif.

3. Perlu memperkuat penegakan hukum dalam kegiatan penagihan pajak serta bekerja sama dengan pemerintah daerah setempat dalam rangka pembentukan alamat wajib pajak yang lebih jelas agar aparat pajak tidak bingung untuk mencari alamat wajib pajak tersebut.

\section{DAFTAR PUSTAKA}

Agoes, Sukrisno.Estralita Trisnawati. 2013. Akuntansi Perpajakan. Edisi 3. Jakarta. Salemba Empat.

Direktorat Jenderal Pajak. Direktorat Jenderal Pemeriksaan dan Penagihan. 2012. Pedoman Penagihan Pajak. Jakarta:Kementerian Keuangan Republik Indonesia.

Fitriandi, Primandita, at al. 2014. Kompilasi Undang-Undang Perpajakan Terlengkap. Penerbit Empa Salemba. Jakarta.

Himpunan Peraturan Perundang-undangan. Pengadilan Pajak dan Penagihan Pajak Dengan Surat Paksa. Edisi 2010. Penerbit Fokusmedia.

Mardiasmo, 2016. Perpajakan. Edisi Revisi 2016. Penerbit Andi. Yogyakarta.

Marhendi, Affan. 2009. Pengaruh Tindakan Penagihan Aktif Dalam Usaha Mencairkan

Tunggakan Pajak Pada KPP Pratama Tamansari Satu Jakarta. Ekonomi Universitas Gunadarma.

M. Rusdji , PPSP Penagihan Pajak dengan Surat Paksa Edisi 2. Penerbit Indeks

Paramita, Ratih Diah Ratna. 2007. Analisis Pengaruh Pelaksanaan Sistem Penagihan Aktif Terhada Tingkat Pencairan Tunggakan Wajib Pajak pada KPP Pratama Batu. Jurnal ekonomi Fakultas Ekonomi Universitas Muhammadiyah Malang. 
Republik Indonesia, Pasal 1 Angka (9). Undang-Undang No.19 Tahun 1997 Tentang Penagihan Pajak Dengan Surat Paksa Sebagimana telah Diubah Dengan UndangUndang No. 19 Tahun 2000.

Republik Indonesia, Undang-Undang No. 28 Tahun 2007 Tentang Perubahan Ketiga atas Undang-Undang No. 6 Tahun1983 Tentang Ketentuan Umum dan Tata Cara Perpajakan.

Resmi, Siti. 2016. Perpajakan Teori dan Kasus Edisi 9. Penerbit Salemba Empat.

Raharjo, Sahid. 2016. Uji Regresi Sederhana Dan Uji Analisis Korelasi Pearson Dengan SPPS.

Sunyoto, Danang. 2013. Metode Penelitian Akuntansi. Penerbit Indeks. Jakarta.

Sumarsan, Thomas. 2013. Perpajakan Indonesia Edisi 3. Penerbit Indeks.

Suandy, Erly. 2014. Hukum Pajak Edisi 6. Penerbit Salemba Empat. 